\title{
Influence of Biology Teachers' on Academic Performance of Students in Senior Secondary Schools in South-West Geopolitical Zone, Nigeria
}

\author{
Abidoye Florence Omosholape, Ogunlowo Simeon Oluwole \\ Department of Science Education, University of Ilorin, Ilorin, Nigeria \\ Email address: \\ abidoye.fo@unilorin.edu.ng (A. F. Omosholape)

\section{To cite this article:} \\ Abidoye Florence Omosholape, Ogunlowo Simeon Oluwole. Influence of Biology Teachers' on Academic Performance of Students in Senior \\ Secondary Schools in South-West Geopolitical Zone, Nigeria. Science Journal of Education. Vol. 9, No. 2, 2021, pp. 40-44. \\ doi: $10.11648 /$ j.sjedu.20210902.13
}

Received: September 17, 2020; Accepted: October 5, 2020; Published: April 23, 2021

\begin{abstract}
The objective of this study was to determine the influence of Biology teachers' on academic performance of students in senior secondary schools in South-West Geopolitical zone, Nigeria. It was a descriptive research of the survey type in which simple random sampling technique was used to select 102 senior secondary schools in South-West zone, Nigeria. Two hundred and four (204) Biology teachers was involved in the study. The data collected were analyzed using frequency count, percentages and t-test. These were used to answer the research questions and also test the hypotheses. The findings of the study showed that Biology teachers generally had positive influence on academic performance of students while there was no significant difference based on gender and years of teaching experience. It is recommended that the adequate instructional materials should be made available for Biology teachers to further enhance their positive influence on the students' academic performance. Both male and female science teachers should be encouraged by provision of special incentive for improvement on their influence on students' academic performance. Both less experienced and experienced Biology teachers should be encouraged to acquire more professional experience in order to improve more on their influence to students' academic performance.
\end{abstract}

Keywords: Influence, Biology Teachers, Academic Performance, Students, Senior Secondary Schools

\section{Introduction}

Science is a systematic process of obtaining testable knowledge about nature and natural occurrence, utilizing careful observation and experimentation [9]. Science is said to be a great enterprise which nations depend on, in order to advance technologically; and therefore, it receives much emphasis in education due to its significance and relevance to life and community [15]. Biology deals with the study of all the varied aspects of living organisms. It is one of the science subjects, offered by candidates sitting for the senior school certificate (SSC) ordinary level examinations. Biology is the most popular subject among the pure science subjects [7].

The position of biology in the education of secondary school students is to give the students the opportunity to manipulate and experiment with suitable equipment and materials. This will prepare them for acquiring adequate laboratory and field skills in biology. "xxxx emphasized the crucial position of biology in the education of secondary school students is to give the students the opportunity to manipulate and experiment with suitable equipment and materials, to prepare them for acquiring adequate laboratory and field skills in biology [8]". Because of the importance of instructional materials, of simple, common and cheap materials can be used to make the lesson interesting and the students to acquire skills and concepts of durable benefits. Material resources can substantially enable education to achieve its goals particularly when the individualization of the learning materials in relation to their effectiveness is carefully considered [13]".

Biology at the senior secondary school level can be grouped under such headings as: Cell and Unicellular Organisms, simple multicellular animals, insects, the arthropods, higher animals, reptiles and birds, mammals, 
flowerless plants, flowering plants, physical processes found in living organisms, respiration, food substances, nutrition of green plants, transport systems, excretion, ecology, etc. [5].

Teachers have various roles to play in the processes of teaching and learning, most especially in teaching of science subjects. For instance, they need to be competent in their subject areas of specialization and also be able to apply different methods of teaching and strategies and understand the learning process of students [11]. The following are the objectives for teaching senior secondary school Biology:

1. To provide basic literacy in Biology for functional living in the society.

2. To acquire essential scientific skills and attitudes as a preparation for the technological application of Biology.

3. To acquire basic concepts and principles of Biology as a preparation for further studies.

4. To stimulate and enhance creativity (NERDC, 2009).

"xxxx observed the impact of Biology teachers on students' performance in Senior Secondary Schools in Osun State, Nigeria and the study found out that Biology teachers had positive impact on students' performance in senior secondary school in Osun State, Nigeria [3]". "xxxx found out the Comparative influence of area of specialization and school type on science teachers' attitude toward teaching in Senior Secondary Schools in Ekiti State [4]". The result indicated that science teachers generally had positive attitude towards science teaching. "xxxx observed the influence of teacher characteristics on achievement of Students in Biology in Osun State, Nigeria. It was found out that Biology teachers had positive influence on students' performance [1]".

Gender determines what is expected, allowed and valued in a woman or a man in a given context. The differences in societal value of men and women in terms of responsibilities, activities undertaken, access and control over resources as well as decision taken are all gender based. "xxxx observed that gender stereotype is responsible for the low representation of women in Science and Technology [14]. "xxxx found out the composite and relative effects of science teachers' gender on attitude to science teaching that does not have influence on students' performance [10]". "xxxx examined the influence of gender on the productivity of secondary school teachers in Delta state, Nigeria [6]". The results of the analysis revealed that although there was no significant difference in the productivity of male and female teachers, the male teachers were generally more productive than their female counterparts and that female teachers were more influenced by location than the male teachers. It was established in the study of " $\mathrm{xxxx}$ that there was no significant difference in the effect of science teachers towards science teaching based on their gender [3]". The males and the female had similar mean attitudinal score; the reason that alluded to this finding may be due to the fact that, male and female science teachers have realized more the importance of science teaching for their future.

Experience is regarded as the best teacher, sequel to this teachers experience is believed to improve mastery of the subject matter being taught, and this might go a long to influence teaching-learning process thereby improving student achievement [2]. It is therefore advisable to keep relatively old hands in the field of teaching. In other for them to be able to transfer skill unto the younger once this could be one of the reasons that the council of Nigeria is clamouring that the retirement age of the teacher should be 65 years. "xxxx found that teachers' years of experience did not significantly contribute to low academic achievement among students in the SMT subjects [12]". "xxxx found that experienced and less experienced teachers had positive views to the performance of ecology teaching in Kwara State [5]".

\subsection{Purpose of the Study}

The purpose of this study was to determine the influence of Biology teachers on academic performance of students in Senior Secondary Schools in South-West Geopolitical zone Nigeria

Specifically, this study found;

1. influence of Biology teachers' on academic performance of students in senior secondary schools in South-West Geopolitical zone Nigeria

2. influence of Biology teachers' on academic performance of students in senior secondary schools based on Gender

3. influence of Biology teachers' on academic performance of students in senior secondary schools based on years of teaching experience

\subsection{Research Questions}

Answers were sought for the following research questions:

1. What is the influence of biology teaching on academic performance of students in senior secondary schools in South-West Geopolitical zone Nigeria?

2. What is the influence of Biology teachers' on academic performance of students senior secondary schools based on gender?

3. What is influence of Biology teachers' on academic performance of students based on years of teaching experience?

\subsection{Research Hypotheses}

The following hypotheses are formulated for testing in this study;

1. There is no significant difference in the influence of Biology teachers on academic performance of students based on their gender?

2. There is no significant difference in the influence of Biology teachers on academic performance of students based on their years of teaching experience?

\section{Methodology}

The descriptive study was conducted by using a survey method. The population was all the Biology teachers in Senior Secondary Schools in South-West Geopolitical zone 
Nigeria. Target population involved was Biology teachers from selected senior secondary schools in South-West Geopolitical zone. The study was carried out in one hundred and two (102) secondary schools in South-West. Two hundred and four (204) Biology teachers both male and female were randomly selected for the study. The study was delimited to only demographic factors such as Teachers' gender, and year of teaching experience. Data regarding the variables such as teachers' gender and years of teaching experience were collected by using a questionnaire that consisted two section (A \& B). Section A consisted personal information about the respondents and section B consisted 40 items on influence of the Biology teachers on academic performance of the students. Data was analysed using frequency count, simple percentage and t-test.

\section{Data Analysis, Result and Summary of Major Findings}

\subsection{Data Analysis and Result}

\subsubsection{Research Question One}

What is the influence of biology teachers on academic performance of students in senior secondary schools in South-West Geopolitical zone Nigeria?

Table 1 shows the numbers and percentages of Biology teachers involved in the study. There are 113 (55\%) male and $91(45 \%)$. The total of the respondent are two hundred and four Biology teachers (204). There was also 135 (66\%) lessexperienced and six- nine (69\%) experienced teachers that were involved in the study.

Table 1. Total Responded of Biology Teachers in Senior Secondary School in South-West Zone, Nigeria based on Gender and Year of teaching experience.

\begin{tabular}{llllll}
\hline Gender & $\begin{array}{l}\text { Total Number of } \\
\text { teachers }\end{array}$ & $\begin{array}{l}\text { Percentage } \\
\text { distributed }\end{array}$ & $\begin{array}{l}\text { Years of teaching } \\
\text { Experience }\end{array}$ & $\begin{array}{l}\text { Total Numbers of } \\
\text { Teachers }\end{array}$ & $\begin{array}{l}\text { Percentage } \\
\text { distributed }\end{array}$ \\
\hline Male & 113 & $55 \%$ & Less-experienced & 135 \\
Female & 91 & $45 \%$ & Experienced & 66.18 \\
Total & 204 & $100 \%$ & & 204 & 23.82 \\
\hline
\end{tabular}

\subsubsection{Research Question Two}

What is the influence of Biology teachers' on academic performance of students senior secondary schools based on gender?

Table 2 shows that the mean scores in the analysis conducted for male was 63.17 and for female was 60.58 and that no significant difference exists between the male and female Biology teachers since the p-value $(0.42)>0.05$. The influence of Biology teachers is positive towards Biology teachers. The null hypothesis $1\left(\mathrm{Ho}_{1}\right)$, which states that there is no significant difference in the influence of Biology teachers' on academic performance of students based on gender, is not rejected.

Table 2. Mean Scores and t-test for testing of Biology teachers in South-West Zone, Nigeria based on Gender.

\begin{tabular}{lllllll}
\hline Gender & No of Respondents & Mean Score & Standard Deviation & Std. Error & $\boldsymbol{t}$ & $\boldsymbol{d}$-value \\
\hline Male & 113 & 63.17 & 4.94 & 0.52 & 1.51 \\
Female & 91 & 60.58 & 4.90 & 0.54 & 1202 \\
Total & 204 & 123.75 & 9.84 & 1.06 & \\
\hline
\end{tabular}

\subsubsection{Research Question Three}

What is influence of Biology teachers' on academic performance of students based on years of teaching experience?

Table 3 shows the mean scores and reveals that there was no significant difference in the teaching of biology teachers on academic performance of students based on their years of experience in South-west geopolitical zone, Nigeria since the p-value $(0.057)>0.05$. The mean scores range between 62.94 and 63.74 with those with less experience having slightly higher positive influence. The null hypothesis 2 $\left(\mathrm{Ho}_{2}\right)$, which states that there was no significant difference in the influence of Biology teachers' on academic performance of students based on years of experience, is not rejected.

Table 3. Mean Scores and t-test for testing Biology Teachers'on the academic performance of Students in South-West Geopolitical Zone, Nigeria based on years of teaching experience.

\begin{tabular}{llllll}
\hline Experience & No of Respondents & Mean Score & Standard Deviation & Std. Error & $\boldsymbol{t}$ \\
\hline Less experience (0-5) & 135 & 63.74 & 6.938 & 0.348 & 1.833 \\
Experience (above 5 years) & 69 & 62.94 & 6.667 & 202 \\
Total & 204 & 126.68 & 13.605 & 0.267 & 0.615 \\
\hline
\end{tabular}

\subsection{Summary of Major Findings}

The research findings of this study as obtained from t-test based on the Research questions and hypotheses are summarized as follows:

1. Biology teachers had positive influence on students' academic performance in senior secondary school in South-West Zone, Nigeria.

2. The influence of Biology teachers on students' academic performance in the secondary school based on gender was not significant.

3. The influence of Biology teachers on academic students' academic performance in the secondary school 
based on their years of teaching experience was not significant.

\section{Discussion of Findings}

In this study, it was found out that influence of Biology teachers on students academic performance in South-West Zone, Nigeria was significant based on their responses. Biology teachers had positive influence on students' academic performance. These can be as a result of helpful behaviour, resourcefulness, enthusiasms, good method of presentation, concern for students and teacher knowledge of the subject matter and the acceptance that they are role model This is in agreement with the findings of " $\mathrm{xxx}$ observed the impact of Biology teachers on students' performance in Senior Secondary Schools in Osun State, Nigeria and the study found out that Biology teachers had positive impact on students' performance in senior secondary school in Osun State, Nigeria [3]". "xxxx Observed the influence of teacher characteristics on achievement of Students in Biology in Osun State, Nigeria. The finding also indicated that Biology teachers had positive influence on students' performance [1]".

It was found in this study that there was no significant difference in the influence of Biology teachers on students' academic performance based on their gender. This may be hinged on the fact that intelligence is not gender based. This study is in agreement with the finding of "xxxx observed teacher gender, qualification and experience as predictors of attitude towards science teaching in Lagos state secondary schools and found out the composite and relative effects of science teachers' gender on attitude to science teaching that does not have influence on students' performance [10]"."Xxxx examined the influence of gender on the productivity of secondary school teachers in Delta state, Nigeria. The results of the analysis revealed that there was no significant difference in the productivity of male and female teachers [6]"

It was found in the study that there was no significant difference in the influence of Biology on students' academic performance based on their years of teaching experience. It may be due to the fact that, the experienced and less experience science teachers are able to concentrate on the most appropriate way to teach particular topics to students who differ in their abilities, prior knowledge and backgrounds. This finding is in agreement with the finding of "xxxx found that teachers' years of experience did not significantly contribute to low academic achievement among students in the SMT subjects [12]". "xxxx observed the effect of qualification and experience of Biology teachers on the status of ecology teaching in Kwara State. The result show that the experienced and less experienced teachers had positive influence on the performance of students in ecology teaching in Kwara State [5]".

\subsection{Conclusion}

Based on the findings of the study, the following major conclusions can be drawn. Biology teachers had positive influence on students' performance in South-West zone, Nigeria and the influence of Biology teachers on students' academic performance based on their gender and years of teaching experience was not significant in the analysis conducted.

\subsection{Recommendations}

Based on the findings of this study, it is hereby recommended that;

1. Adequate instructional materials should be made available for Biology teachers to further enhance their positive influence on the students' academic performance.

2. Both male and female science teachers should be encouraged by provision of special incentive for improvement on their influence on students' academic performance.

3. Both less experienced and experienced Biology teachers should be encouraged to acquire more professional experience in order to improve more on their influence to students' academic performance.

\section{References}

[1] Abidoye, F. O. (2019): Influence of Teacher Characteristics on Achievement of Students in Biology in Osun State, Nigeria. ATBU, Journal of Science, Technology \& Education (JOSTE) 7 (2), 255-260.

[2] Abidoye, F. O., Ahmed, M. A. and Olorundare, A. S. (2019) Effectiveness of ICT on Teachers' Science teaching to Secondary Schools in Irepodun Local Government Area, Kwara State, Nigeria Huril Journal 26 (1) pg 1-11.

[3] Abidoye, F. O. (2018). Impact of Biology Teachers on the Students' Performance in Senior Secondary School in Osun State, Nigeria. European Journal of Health and Biology Education 7 (2) 35-40.

[4] Abidoye, F. O. and Olorundare, A. S. (2018): Comprising of the Area of subject Specialization and School type of science teachers' attitude toward science teaching in senior secondary schools in Ekiti State, Nigeria. FUOYE Journal of Education. Faculty of Education, Federal University, Oye Ekiti, Nigeria 1 (2) pp 129-133.

[5] Abidoye, F. O. (2017) Effect of Qualification and Experience of Biology Teachers on the Status of Ecology Teaching in Kwara state. Ilorin Journal of Education 36 (1) pp 117-125.

[6] Abiri, A. A.\& Ugborugbbo, N. M.(2008). An examination of genders' influence on teachers' productivity in secondary school. Journal of social science 17, (3), 185-191.

[7] Idodo-Umeh, G. (2010). College Biology. Idodo-Umeh Publishers Limited, Benin City, Edo State.

[8] Ifeobu, H. N. (2014). Evaluation of the implementation of national curriculum for secondary school biology in Anambra state. University of Nigeria Virtual Library.

[9] Okeke, E. A. C. (2007). Making Science Education Accessible to all. $23^{\text {rd }}$ Inaugural Lecture Series, University of Nigeria, Nsukka. 
[10] Olaoye, R. A. \& Ogunkola, B. J. (2004). Teacher gender, qualification and experience as predictors of attitude towards science teaching in Lagos state secondary schools. International Journal of Emotional Psychology and Sport.

[11] Ololube, N. P. (2009). Understanding Teachers' Professional Competencies for Education Effectiveness. Owerri: Springfield Publishers Ltd.

[12] Musau L. M. \& Abere M. J. (2015). Teacher qualification and students' academic performance in science mathematics and technology subjects in Kenya; International Journal of Educational Administration and Policy Studies 7 (3), pp. 8389.
[13] Nigeria Education Research and Development Council (2009). Senior Secondary Education Curriculum Biology for SS 1-3 published by Federal Ministry of Education of Nigeria pp 2022 .

[14] Nsofor, C. C. (2000). The need to involve women in the development of science and technology in the millennium. A paper presented at the second international conference of the NAWACS, Abuja.

[15] Nwagbo, C. R. (2008). Practical approach to effective teaching of local and major biotic communities (Biomes) to Secondary School Students for Sustainable Development. Science Teachers' Association of Nigeria (STAN) Biology Panel series. pp 41-55. 